\title{
DETERMINING THE EFFECTS OF POLLUTANTS ON SOME TYPES OF MICRO ALGAE AND MYTILUS GALLOPROVINCIALIS (LAMARCK,
} 1819)

\author{
Arzu Morkoyunlu Yüce ${ }^{* 1}$ 价 \\ ${ }^{* 1}$ Kocaeli University, Hereke Asım Kocabıyık Uzunyol Vocational Schools, 41000 Kocaeli/Turkey
}

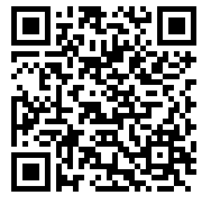

DOI: https://doi.org/10.29121/granthaalayah.v8.i10.2020.2074

Article Type: Research Article

Article Citation: Arzu Morkoyunlu Yüce. (2020). DETERMINING THE EFFECTS OF POLLUTANTS ON SOME TYPES OF MICRO ALGAE AND MYTILUS GALLOPROVINCIALIS (LAMARCK, 1819). International Journal of Research GRANTHAALAYAH, 8(10), 319-322. https://doi.org/10.29121/granthaa layah.v8.i10.2020.2074

Received Date: 15 October 2020

Accepted Date: 31 October 2020

Keywords:

Algae

Mussels

Water pollution

Environment

\section{ABSTRACT}

This study was conducted to determine the effects of aquatic pollutants on aquatic organisms. Izmit Bay, which is polluted both domestically and industrially, was chosen as the study area. Densely populated areas and industry are located around the Izmit Bay. For this purpose, mussel and micro algae samples were taken from selected stations. In the study, salinity value was measured in the range of $22 \%$ $28 \%$. Water temperature, $\mathrm{pH}$ and conductivity varied from $9.20-25.01{ }^{\circ} \mathrm{C}$, $6.81-8.3,30.42-45.11 \mu \mathrm{S} / \mathrm{cm}$, dissolved oxygen values as minimum and maximum 4.62 - $12.61 \mathrm{mg} \mathrm{l}-1$ were determined respectively. In heavy metal analyses $\mathrm{Al}, \mathrm{Mn}, \mathrm{Zn}, \mathrm{Cu}, \mathrm{Pb}, \mathrm{Cr}, \mathrm{Ni}, \mathrm{Cd}$ and $\mathrm{Fe}$ ) of seawater were determined in the study. As a result of the study, the highest heavy metal ratio in Mytilus galloprovincialis was determined to be iron. In the study, Oscilatoria sp., Ulnaria sp. and Nitzschia sp. taxa were determined as dominant. These species have high tolerance to aquatic pollution parameters.

\section{INTRODUCTION}

Environmental parameters are effective on both terrestrial and aquatic ecosystems. It is very important to determine the factors that cause the temporal changes of the physical and chemical properties of sea water. Izmit Bay is an economically and ecologically important region.

The bay, marine transportation, residential areas and marine ecosystems is an area that should be examined in terms of diversity. Therefore, a lot of research has been done in the region and it is still being done. The environment sea water pollution problems have increased since 1960 due to the rapid growth of heavy industry and population growth in the Izmit area. Plants have been built in the area surrounding the bay (Morkoç et al., 2001). Previous research in Izmit Bay showed that the bay's sea waters have been eutrophic (Tuğrul et al., 1986; Morkoç et al., 2001). Many researches have been carried out in Izmit Bay from past to present. In these studies, it was determined that bay is under the influence of different pollutants (Legoviç et al. 1994; Morkoç et al. 1994; Morkoç et al. 1997; Algan et al. 1999; Okay et al., 2001) It has been stated that in the micro algae composition of Izmit Bay, species that have adapted to eutrophic conditions and have high pollution tolerance show spread (Yerli et al. 2006; Küçük and Ergül, 2011; Morkoyunlu Yüce 2017). In these studies, wave movements, environmental effects, annual water regime,

(C) 2020 The Author(s). This is an open access article distributed under the terms of the Creative Commons Attribution License, which permits unrestricted use, distribution, and reproduction in any medium, provided the original author and source are credited. 
climatic effects and physicochemical parameters were determined effective in distribution. This study was conducted to determine the effects of aquatic pollutants on aquatic organisms.

\section{MATERIALS AND METHODS}

İzmit Bay is 50-km-long and 1.8-9 km wide and has a surface area of $261 \mathrm{~km}^{2}$. İzmit Bay is located between $29^{\circ}$

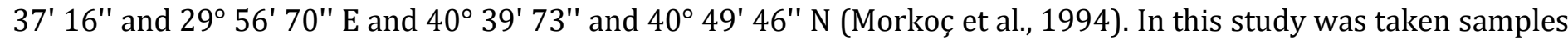
of sea water, micro algae and mussel (Mytilus galloprovincialis). The research area and stations are given in figure 1 .

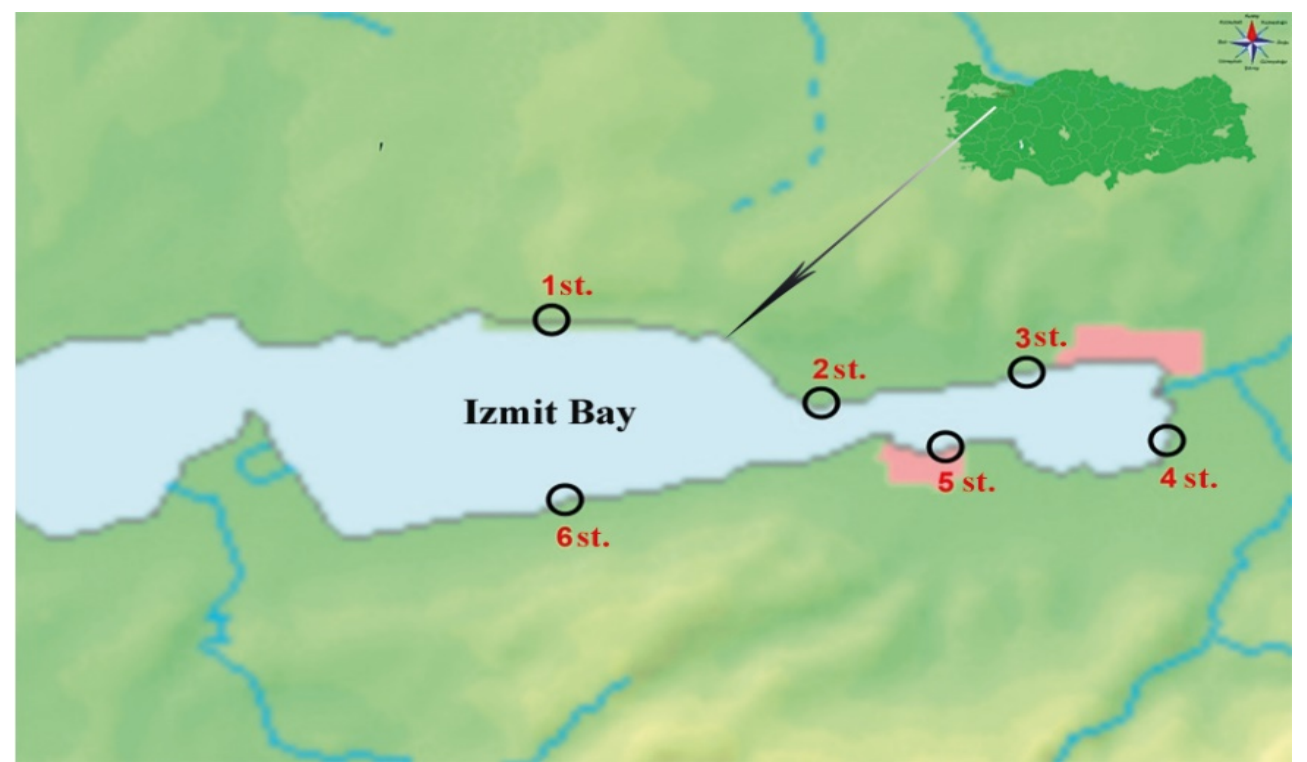

Figure 1: The research area in Izmit Bay (http://www.koeri.boun.edu.tr.sismo.map)

\subsection{SAMPLE COLLECTION AND ANALYTICAL PROCEDURE}

In this study, microlgae samples were collected in a littoral region (up to $2 \mathrm{~m}$.) and brought to the laboratory in labelled bags. Mussel samples were taken and laboratory procedures were done according to standard techniques and methods (Bernhard 1976). After proper pretreatment (Hot Plate Heating, Microwave Pretreatment), metals were analyzed by ICP-OES. In this study, EPA METHOD 200.7 and ICP- OES analysis method was applied. Sea water were measured by using an Agilent 7700 series ICP-MS instrument. Other. Physico-chemical parameters were measured in situ with the YSI multiparameter at the time of sampling.

\section{RESULT AND DISCUSSION}

The heavy metal levels of Mytilus galloprovincialis, Fe (144.07 \pm 37.62$)$, Al (92.54 \pm 22.05$)$, $\mathrm{Cu}(55.50 \pm 16.48)$, Mn (24.74 \pm 5.32$)$, Zn (22.54 \pm 4.58$)$, Cr (12.53 \pm 2.31$)$, Pb (3.63 \pm 0.97$)$, Ni (1.86 \pm 0.17$)$ and Cd (1.06 \pm 0.04$)$ were determined. The heavy metal levels in Mytilus galloprovincialis was determined as $(\mathrm{Fe}>\mathrm{Al}>\mathrm{Cu}>\mathrm{Mn}>\mathrm{Zn}>\mathrm{Cr}>\mathrm{Pb}>\mathrm{Ni}>\mathrm{Cd})$. In the Mytilus galloprovincialis in research stations, iron was determined to be at the highest ratio. These results were given in figure 4. 


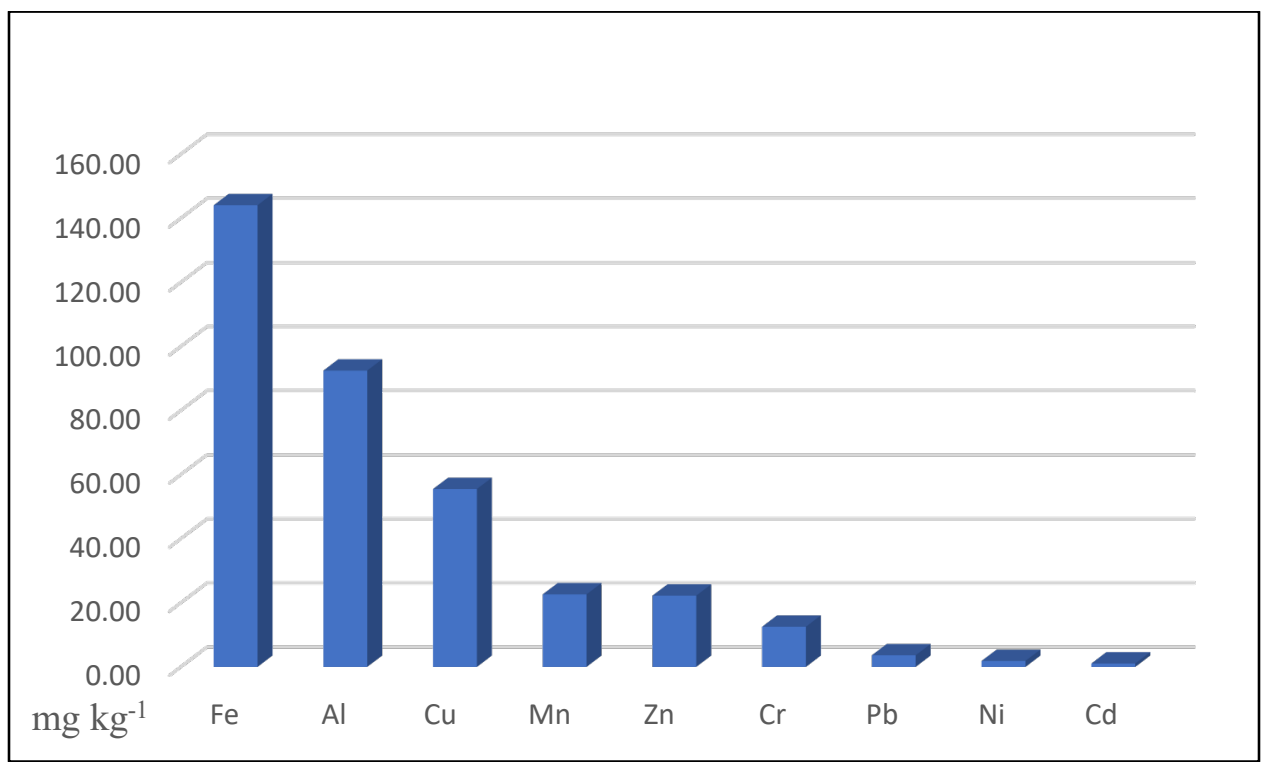

Figure 4: Heavy metal concentrations in Mytilus galloprovincialis (mg kg-1/ age weight)

It has been determined that aquatic pollutants are effective in the distribution of species in micro algae samples. Especially, species with high pollution tolerance were identified. In the study, Oscilatoria sp., Ulnaria sp. and Nitzschia sp. taxa were determined as dominant.

In the study, the salinity value was measured in the range of $22 \%$ - $28 \%$. Average value of water temperature, $\mathrm{pH}$ and conductivity varied from $16.91{ }^{\circ} \mathrm{C}, 7.46,37.85 \mu \mathrm{S} / \mathrm{cm}$, and the dissolved oxygen values as $9.14 \mathrm{mg} \mathrm{l}^{-1} \mathrm{were}^{\circ}$ determined respectively. Sea water temperature was the lowest at the first station as $9.2^{\circ} \mathrm{C}$ and the highest as $25^{\circ} \mathrm{C}$ were measured at the third station. The annual average water temperature in the İzmit Bay was determined as $16.91^{\circ} \mathrm{C}$. Although there is a difference in temperature between stations, it was found to be seasonally appropriate. Electrical conductivity, at the lowest $30.2 \mu \mathrm{S} / \mathrm{cm}$ and the highest $45.1 \mu \mathrm{S} / \mathrm{cm}$ were measured at the third station. The annual average electrical conductivity value was determined as $37.85 \mu \mathrm{S} / \mathrm{cm}$. The $\mathrm{pH}$ value was the lowest at the first station as 6.9 and the highest as 8.3 were measured at the sixth station. The annual average pH value was determined as 7.46. There was no significant difference in the $\mathrm{pH}$ values among the stations. The dissolved oxygen value was the lowest at the third station as $4.6 \mathrm{mg} \mathrm{l}^{-1}$ and the highest as $12.7 \mathrm{mg} \mathrm{l}^{-1}$ at the first station. The average dissolved oxygen value of the Bay at $9.14 \mathrm{mg} \mathrm{l}^{-1}$ was determined. According to the dissolved oxygen values, there was an increase in the oxygen level with the decrease of the water temperature in winter months, while a decrease in the oxygen level was determined in summer because of the increase in the water temperature. In the study, the lowest oxygen value was determined at the third station. This result was thought to be due to the fact that this station is very dirty in terms of organic wastes. The water depth was low, the stationary water movements increased the pollution load in this region, and this was determined as a dirty area. When all stations were examined according to their $\mathrm{pH}$ values, it was determined that sea water showed slightly alkaline properties. In the research, the sixth station was determined as the cleanest zone compared to other stations. The fact that the sixth station is far from domestic and industrial settlement has been effective in this situation.

\section{CONCLUSIONS}

Sea ecosystems are one of the most important life sources of the earth's ecosystem with their physical, chemical and biological structures. In the study, it was aimed to evaluate İzmit Bay regarding the relationship between the biological and environmental parameters. In general, It was concluded that heavy industry, ship transport and domestic wastes around the bay were still effective on the marine ecosystem. In recent years, environmental inspections in the Izmit Bay, collection of ship wastes, sea surface cleaning, stream recreation and monitoring of sea water quality are carried out regularly by the relevant legal institutions. As a result, it is very important for these applications to be sustainable for aquatic environmental management. 


\section{SOURCES OF FUNDING}

This research received no specific grant from any funding agency in the public, commercial, or not-for-profit sectors.

\section{CONFLICT OF INTEREST}

The author have declared that no competing interests exist.

\section{ACKNOWLEDGMENT}

This research was supported by Kocaeli University, BAP Unit (project number: 2017/078). I would like to thank Kocaeli University for their support.

\section{REFERENCES}

[1] Morkoç, E., Okay, S., Tolun, L., Tüfekçi, V., Tüfekçi, H., Legoviç, T. Towards a Clean İzmit Bay, Environment International, 26, 2001, 157-161. https://doi.org/10.1016/S0160-4120(00)00103-3

[2] Tuğrul, S., Sunay, M., Baștürk, Ö., Balkaș, T.I. The İzmit Bay Case Study, In the Role of Oceans as a Waste Disposal Option, ed. G. Kullenberg, 1986, 243-275.

[3] Legoviç, T., Morkoç, E., Okay, O.S., Egesel, L., Tüfekçi, V., Tüfekçi, H. Mass Balance of Total Phosphorus in the İzmit Bay. International Specialised Conference on Marine Disposal Systems, 1994, 345-350. https://doi.org/10.1016/0273-1223(95)00585-B

[4] Morkoç, E., Tuğrul, S., Okay, O.S., Legoviç, T. Eutrophication, Limiting Nutrient and Hydrochemical Characteristics of the Polluted Bay of İzmit, Result of Four-Years Data. International Specialized Conference on Marine Disposal Systems, Nov., 1994, 335-344.

[5] Morkoç, E., Tuğrul, S., Okay, O.S., Legoviç, T. Eutrophication of the İzmit Bay, Marmara Sea. Croatica Chemica Acta, 70, 1997, 347-359.

[6] Algan, O., Altıok, H. and Yüce, H. Seasonal Variation of Suspended Particulate Matter in Two-layered Izmit Bay, Turkey. Estuarine, Coastal and Shelf Science, 49, (1999). 235-250. https://doi.org/10.1006/ecss.1999.0494

[7] Okay, O.S., Tolun, L., Telli Karakoç, F., Tüfekçi, V., Tüfekçi, H., Morkoç, E. İzmit Bay (Turkey) Ecosystem After Marmara Earthquake and Subsequent Refinery Fire: Long-Term Data. Marine Pollution Bulletin, 42(5), 2001, 361-369. http://dx.doi.org/10.1016/S0025-326X(00)00163-6

[8] Yerli, B., Cebeci, M., Göksungur, E.G., Erdem, Ü. Distribution of Phytoplankton with Nutrient in İzmit Bay. Anadolu University Journal of Science and Technology, 7 (1), 2006, 229-237.

[9] Küçük, A., Ergül, H.A. Seasonal Variations of Microplankton Composition in İzmit Bay (Sea of Marmara). Journal of the Black Sea / Mediterranean Environment, 17(3), 2011, 216-222.

[10] Morkoyunlu Yüce, A. Determination of Environmental Factors and Littoral Phytoplankton in İzmit Bay. International Journal of Aquatic Science, 8 (1) 2017., 3-8.

[11] Bernhard, B. Manual of Methods in Aquatic Environment Research. Part. 3 Sampling and Analyses of Biological Materials. Guidelines for the FAO (GFCM)/UNEP Joint Coordinated Project on Pollution on Mediterranean, 1976,124 . 